with the corresponding halves of the hyoid bone and thyroid cartilage, a tolerable view of the position of the parts was obtained. The epiglottis was in direct apposition by its laryngeal surface with the posterior wall of the pharynx, so as to preclude the possibility of the passage of air. When, however, the head was allowed to hang backwards over the edge of the table, the bending of the cervical vertebræ caused the posterior wall of the pharynx to recede from the epiglottis, so as to allow the free passage of air."

Should the pulling up of the chin not remove the stertor, turn the patient slowly and gently on to the left side, then pass the finger into the mouth, and pull forward the tongue. Do not be content with merely drawing the tip of the tongue beyond the margin of the teeth, but take firm hold of it with a pair of artery forceps, and pull it forcibly forwardsa proceeding which is usually at once followed by a full deep inspiration. Mr. Bader does not offer us any explanation of the beneficial effects resulting from placing patients on the left side. It may be that the right side of the heart is more free to act in this position. The rolling of the patient on to his side is one of the procedures in the Marshall Hall method of artificial respiration. At Guy's Hospital, during the last six years, it has been the only means adopted in cases of danger. It is customary, in operations about the female genitals or for piles, to place the patient on the left side, and I never remember observing serious symptoms with patients in this position. During sleep, a condition allied to anæsthesia, it is certain that ninety-nine out of a hundred of us choose one side or the other to lie upon. These disjointed reflections make me very strongly disposed to think that Mr. Bader's advice is sound, and should an occasion arise I should most certainly act upon it.

Pulling forward the tongue was first suggested by Bickersteth on the ground that the tongue fell back upon the top of the larynx and obstructed it. He considered that the pulling forward of the tongue acted merely mechanically. Lister asserts that it acts through the nervous system, and that a good hard tug with the artery forceps calls the muscles of the larynx into play, and removes the obstruction. The use of the artery forceps is of no consequence, because the patient when he recovers merely thinks that he has bitten his tongue. I believe, however, that the pulling forward of the tongue acts mechanically as well, for I have often observed the tip of the tongue lying against the roof of the mouth, and effectually preventing the passage of air. This only occurs when the patient is lying on his back, and cannot take place when he is on his side. This is another reason for following Mr. Bader's advice.

(To be concluded.)

\section{A CASE OF}

\section{GREAT DEFORMITY OF THE LOWER EX- TREMITIES SUCCESSFULLY TREATED WITHOUT AN OPERATION.}

By LUTHER HOLDEN, F.R.C.S., SURGEON TO ST. BARTHOLOMEW'S HOSPITAL.

G. M-, aged sixteen, was admitted into St. Bartholomew's Hospital, under my care, June $30 \mathrm{th}, 1871$. A cast, of which Fig. 1 is a drawing, was ordered to be taken that some idea might be formed of the progress of the case. The legs were carefully bandaged, and placed in splints, and the patient confined to bed. The splints were made of strong beech, similar in some respects to M'Intyre's, but hinged in the lateral direction, that for the right leg being placed with the screw inside, and that for the left on the outside of the limb. There was an additional rack movement, so that the splint might be slightly flexed, and to each was attached a foot-board. The splints were then brought, by means of the screws, as near the shape of the limbs as possible, the feet being firmly bandaged to the foot-boards, and the bandaging continued up to the thigh. In this position they were left for a few days before commencing any pressure. The pressure when commenced was very gently applied. The splints were removed once a week, and the limbs washed and carefully dried. Notwith- standing every care, a small blister came on the heel, in consequence of which the splint was discontinued on the left leg for more than a fortnight. The treatment of the genu valgum in the flexed position was very successful before resorting to immediate pressure in the lateral direction.

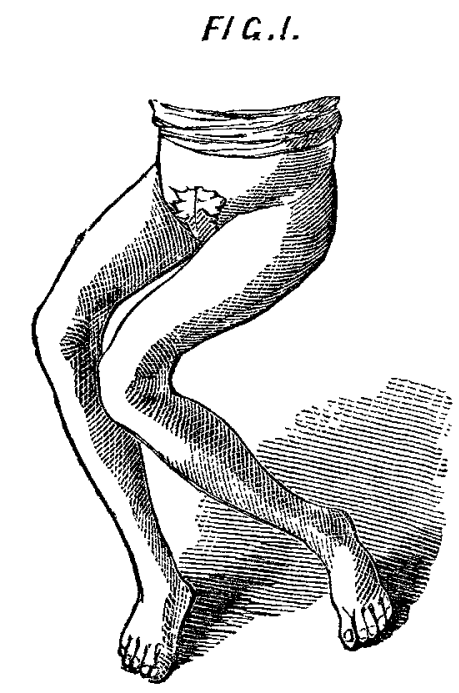

FIC: 2

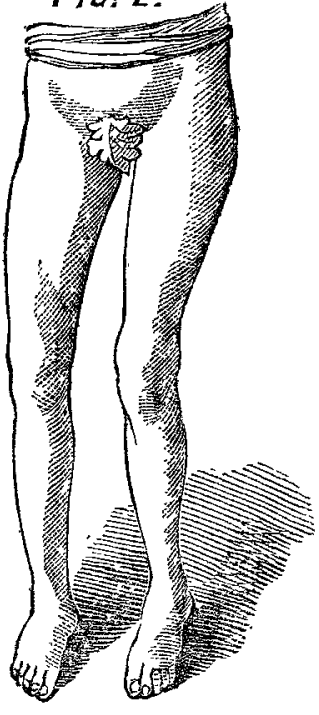

A set of instruments was ordered for him, with boots, and he was discharged from the hospital on Jan. 26th, 1872. The instruments consisted of steel supports up both sides of the legs, attached to a pelvic band. The knees were not allowed to bend, and he was directed to use crutches. First one crutch, then the other, was discontinued; and at the period of taking the cast of Fig. 2, in August, he could walk about comfortably, without any assistance except the instruments, which he was instructed to use for some time to come.

It is but just to state that for part of the time the patient was in hospital he was under the care of Mr. A. Willett, assistant-surgeon.

The splints and instruments were constructed by M.r. Pratt, mechanician to the hospital.

Gower-street, W.C.

\section{THIRD SERIES OF FIFTY CASES OF OVARIOTOMY.}

Bx T. KEITH, F.R.C.S. EDIN.

THE accompanying table gives a third series of fifty cases of ovariotomy. The first and second series are recorded in The LanceT of Sept. 7th, 1867, and Aug. 20th, 1870. Details of this series of cases will shortly appear in the Edinburgh Medical Journal.

In one case (June 29th, 1872) ovariotomy was not completed on account of intimate adhesion between some folds of cancerous intestine and the posterior wall of the cyst. The case had seemed a favourable one; the general condition was good, and the cyst moved freely with respiration. The patient got over the immediate effects of the operation, but died at the end of five weeks from the cancerous affection.

Of the last hundred cases there have been eighty-four recoveries. Of the eight fatal cases in the present series, two died from obstructed intestine, one from acute septicæmia, and five from peritonitis. In two of these adhesions were considerable, in one moderate; while in five the tumours were non-adherent.

In nearly all the fatal cases the general condition of the patient was bad. They were all poor women, pretty much worked out, though the tumours were of only moderate size. The result in the 106th case was very disappointing. Everything was most favourable for a successful termination, yet the patient died from diffuse peritonitis, in a way I never saw before nor since.

In six of the fatal cases the clamp was used. In one, catgut ligatures to one orary and clamp to the other; in 
another, the long ligatures of Dr. Clay. In nearly one-third ment in the general health followed the tapping. One had of the cautery cases bleeding took place from large vessels, been tapped twenty times, another fourteen times, before and ligatures were necessary. Many of the cases had been operation yet both made excellent recoveries. Only one of tapped once or of tener; and, as a rule, a manifest improve- the fatal cases had been tapped. It was that of a young

\begin{tabular}{|c|c|c|c|c|}
\hline No. & DAte. & AGE. & Adiestons; Weight of Tumour; Treatment of Pedicle. & RESULT. \\
\hline 101 & April, 1870 & 35 & Suppurating cyst. $30 \mathrm{lb}$. Parietal adhesions. Cautery. & Recovered. \\
\hline $\begin{array}{l}102 \\
103\end{array}$ & ril & 51 & Slight adhesions. $35 \mathrm{lb}$. Clamp. & " \\
\hline $\begin{array}{l}103 \\
104\end{array}$ & May & 61 & No adhesions. $39 \mathrm{lb}$. Semi-solie. Cautery. & ", \\
\hline $\begin{array}{l}104 \\
105\end{array}$ & June & 27 & Extensive parietal, abdominal, and intestinal adhesions. $12 \mathrm{lb}$. Ascites. Cautery. & " \\
\hline $\begin{array}{l}105 \\
106\end{array}$ & June & 47 & Adhesions to intestine, wall, and omentum. $10 \mathrm{lb}$. Ascites. Long ligatures. & Died" \\
\hline $\begin{array}{l}106 \\
107\end{array}$ & Sept. & 49 & No adhesions. $12 \mathrm{lb}$. Clamp. & $\begin{array}{l}\text { Died. } \\
\text { Recovered }\end{array}$ \\
\hline 87 & Sept. & $\begin{array}{l}30 \\
23\end{array}$ & $\begin{array}{l}\text { No adhesions. } 21 \mathrm{lb} \text {. Clamp. } \\
\text { Omental adhesions. Suppurating dermoid cyst. } 20 \mathrm{lb} \text {. Clamp. }\end{array}$ & $\begin{array}{l}\text { Wecovered. } \\
\text { Died. }\end{array}$ \\
\hline 109 & $\begin{array}{l}\text { Uct. } \\
\text { Oct. }\end{array}$ & 20 & $\begin{array}{l}\text { Omental adhesions. Suppurating dermoid cyst. 2010. Cratep. } \\
\text { Parietal adhesions. } 19 \mathrm{lb} \text {. Clamp. }\end{array}$ & Recovered. \\
\hline 110 & Oct. & 23 & Parietal and extensive pelvic adhesions. $18 \mathrm{lb}$. Cautery. & , \\
\hline $\begin{array}{l}111 \\
112\end{array}$ & Nov. & $\mathbf{4 4}$ & Omental adbesions. 25 lb. Clamp. & , \\
\hline $\begin{array}{l}112 \\
113\end{array}$ & Nov. & $\begin{array}{l}44 \\
23\end{array}$ & $\begin{array}{l}\text { Very extensive adhesions. } 37 \mathrm{lb} \text {. Clamp. } \\
\text { Universal adhesions. } 80 \mathrm{lb} \text {. Cautery. }\end{array}$ & $"$ \\
\hline $\begin{array}{l}113 \\
114\end{array}$ & $\begin{array}{l}\text { Dec. } \\
\text { Dec. }\end{array}$ & $\begin{array}{l}23 \\
23\end{array}$ & $\begin{array}{l}\text { Universal adhesions. } 80 \mathrm{lb} \text {. Cautery. } \\
\text { No adhesions. } 10 \mathrm{lb} \text {. Both ovaries removed. Catgut ligatures and clamp. }\end{array}$ & Died”. \\
\hline 115 & Jan. 1871 & 33 & No adhesions. $27 \mathrm{lb}$. Clamp. & Died. \\
\hline 116 & $\mathrm{Ja}$ & 19 & No adhesions. $20 \mathrm{lb}$. Clamp. & Recovered. \\
\hline 117 & $\mathrm{Fe}$ & 54 & No adhesions. $57 \mathrm{lb}$. Clamp. & corered. \\
\hline 118 & $\mathrm{M}$ & 54 & No adhesions. Semi-solid. $17 \mathrm{lb}$. Long ligatures. & Died. \\
\hline 20 & $\begin{array}{l}\mathrm{M} \\
\mathrm{A}_{1}\end{array}$ & 16 & $\begin{array}{l}\text { No adhesions. } 15 \mathrm{lb} \text {. Clamp. } \\
\text { Slight adhesion in pelvis. } 22 \mathrm{lb} \text {. }\end{array}$ & Recovered. \\
\hline 121 & A & 25 & $\begin{array}{l}\text { Slight adhesion in pelvis. } 22 \mathrm{lb} \text {. } \\
\text { No adhesions. } 20 \mathrm{lb} \text {. Clamp. }\end{array}$ & ", \\
\hline 122 & & 35 & $\begin{array}{l}\text { No adhesions. } 2016 \text {. Clamp. } \\
\text { Parietal adhesions. } 36 \mathrm{lb} \text {. Clamp. }\end{array}$ & ", \\
\hline 123 & & 47 & No adhesions. $45 \mathrm{lb}$. Clamp. & ?" \\
\hline 124 & & 61 & Parietal adhesions. $25 \mathrm{lb}$. Rupt & Died. \\
\hline 125 & & 25 & Omental adhesions. $10 \mathrm{lb}$. Semi-solid. Ascites. $\mathrm{Cl}$ & Recovered. \\
\hline 126 & $\mathrm{~J}$ & 35 & Adhesions universal, extensive intestinal and pelvic. Suppurating cys & ", \\
\hline 127 & $\mathbf{S}$ & 35 & Adhesions, parietal, intestinal, \& in pelvis to uterus. Suppurating cyst. 28lb. Clamp. & ", \\
\hline 12 & & 32 & Extensive parietal, omental, and pelvic adhesions, also to liver. $30 \mathrm{lb}$. Clamp. & " \\
\hline 130 & $\mathrm{O}$ & $\begin{array}{l}50 \\
45\end{array}$ & $\begin{array}{l}\text { No adhesions. } 40 \mathrm{lb} \text {. Clamp. } \\
\text { Extensive narietal adhesions. } 52 \mathrm{lb} \text { Both ovaries removed. Catgut ligatures. }\end{array}$ & $"$ \\
\hline $\begin{array}{l}130 \\
131\end{array}$ & $\stackrel{\mathrm{O}}{\mathrm{N}}$ & $\begin{array}{l}45 \\
45\end{array}$ & $\begin{array}{l}\text { Extensive parietal adhesions. } 52 \mathrm{lb} \text {. Both ovaries removed. Catgut ligatures. } \\
\text { Parietal, mesenteric, and intestinal adhesions. } 41 \mathrm{lb} \text {. Clamp. }\end{array}$ & 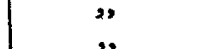 \\
\hline $\begin{array}{l}131 \\
132\end{array}$ & $\begin{array}{l}\text { Nov. } \\
\text { Nov. }\end{array}$ & $\begin{array}{l}45 \\
52\end{array}$ & $\begin{array}{l}\text { Parietal, mesenteric, and intestinal adhesions. } 41 \mathrm{lb} \text {. Clamp. } \\
\text { No adhesions. } 30 \mathrm{lb} \text {. Clamp. }\end{array}$ & ", \\
\hline 133 & $\mathrm{D}$ & 5 & No adhesions. Almost solid tumour. $22 \mathrm{lb}$. Clamp. & " \\
\hline 134 & D & 52 & Parietal, omental, and mesenteric adhesions. $36 \mathrm{lb}$. Clamp. & $s$ \\
\hline 135 & De & 34 & Extensive parietal and omental adhesions. $42 \mathrm{lb}$. Clamp. & , \\
\hline 136 & & 25 & No adhesions. Semi-solid. $7 \frac{1}{2} \mathrm{lb}$. Clamp. & \\
\hline 137 & 72 & 35 & Extensive parietal adhesions. $36 \mathrm{lb}$. Clamp. & Dic \\
\hline 138 & & 42 & Parietal and omental adhesions. 4 gals. fluid. Clamp. & $\mathbf{R}$ \\
\hline 139 & A & 44 & Extensive parietal and omental adhesions. $18 \mathrm{ll}$. Clamp. & Di \\
\hline 140 & May & 48 & No adbesions. $7 \mathrm{lb}$. 4 gals. ascitic fluid. Cautery. & Recovered. \\
\hline 141 & $\mathrm{Ju}$ & 31 & No adhesions. $2 \frac{1}{2} \mathrm{lb}$. Ascitic fluid. Cautery. & " \\
\hline 142 & $\mathrm{Ju}$ & 27 & No adhesions. $22 \mathrm{lb}$. Clamp. & ", \\
\hline 143 & June & 40 & $\begin{array}{l}\text { No adhesions. } 18 \mathrm{lb} \text {. Clamp. } \\
\text { Adhesions universal, intestinal and pelvic, and to bladder and rectum. Tapped ? }\end{array}$ & "3 \\
\hline 144 & June & 57 & $\begin{array}{l}\text { Adbesions universal, intestinal and pelvic, and to bladder and rectum. Tapped } \\
20 \text { times. } 50 \mathrm{lb} \text {. Cautery. }\end{array}$ & ", \\
\hline 145 & $\mathrm{Ju}$ & 17 & Extensive parietal adhesions. $51 \mathrm{lb}$. Cautery. & , \\
\hline 146 & $\mathrm{~J}$ & 20 & No adhesions: $20 \mathrm{lb}$. Cautery. & 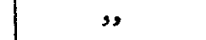 \\
\hline 147 & Julg & 40 & Adhesions universal, especially in pelvis. 30lb. Suppurating cyst. Cautery. & "’ \\
\hline 148 & & 40 & No adhesions. 54lb. Clamp. & " \\
\hline 14 & $\begin{array}{l}\text { Aug. } \\
\text { Sept. }\end{array}$ & $\begin{array}{l}35 \\
57\end{array}$ & $\begin{array}{l}\text { Extensive parietal adhesions. } 60 \mathrm{lb} \text {. Tapped 14 times. Cautery. } \\
\text { Parietal, omental, and intestinal adhesions. } 25 \mathrm{lb} \text {. Suppurating cyst. Cautery. }\end{array}$ & , \\
\hline 15 & Sept. & 57 & & \\
\hline
\end{tabular}

girl dying from a suppurating cyst. Ovariotomy was performed a few days after, but it did not save her. Yet in this series, in other five as hopeless-looking cases of suppurating cyst with septic fever, operation was perfectly successful.

Except that the cautery has sometimes been used in dividing the pedicle, there has been little change in the way of operating or in the general management of the cases since last report. During the operation perhaps more care than ever is taken to tie every bleeding point; and it need hardly be added that Lister's animal ligatures are now rased. After operation the same precautions are taken in restricting the giving of food and stimulants, especially food.

As an anæsthetic, pure, dry sulphuric ether (Macfarlane's) made from methylated alcohol is always used, and with the best results, especially in the very feeble women. Of one hundred cases in which sulphuric ether has now been given, there have been only thirteen deaths.

Edinbargh.
THE PRESENCE OF AN ENCYSTED ECHINORHYNCHUS IN MAN.

Br F. H. WELCH, F.R.C.S.,

STAFF ASSISTAYT-SURGEON, ASSTSTANT TO THE PROFBSSOR OF PATHOLOGT, ROYAL VICTORIA HOSPITAL, NETLEY.

THE subject from which the present example was taken was a soldier, aged thirty-four, with sixteen years' service, the last fourteen of which had been continuously in India. The stations in which he had been quartered were numerous and diversified; the diseases from which he had suffered were, malarial fever, frequent diarrhœa, bronchitis, pneumonia, and phthisis. The latter disease caused his being invalided from Kussowlie after five months' duration, and his death at Netley six days after admission. From this it may be assumed that the parasite was received into the body in India. 